\title{
Efektivitas Air Rebusan Daun Binahong Terhadap Penyembuhan Ruptur Perineum Pada Ibu Bersalin Di Puskesmas Menes Kabupaten Pandeglang
}

\author{
Triana Indrayani*, Fitri Mulyani Solehah, Retno Widowati \\ Fakultas Ilmu Kesehatan, Universitas Nasional, Jakarta, Indonesia \\ Corresponding author: Triana Indrayani (trianaindrayani@civitas.unas.ac.id) \\ Received: Mei, 20 2020; Accepted: June, 28 2020; Published: September, 12020
}

\begin{abstract}
ABSTRAK
Angka Kematian Ibu (AKI) di Pandeglang tahun 2017 sebesar 95 per 100.000 kelahiran hidup. Kematian ibu disebabkan oleh perdarahan postpartum (34\%), infkesi jalan lahir (14\%), eklampsia (11\%) dan sebab lain (46\%). Data Puskesmas Menes tahun 2019 menunjukkan bahwa ibu postpartum yang mengalami ruptur perineum sebanyak 30 orang.

Desain penelitian menggunakan quasi experiment two group with control post test design. Sampel dalam penelitian sebanyak 30 responden yang terdiri dari 15 orang kelompok intervensi dan 15 orang kelompok kontrol. Teknik pengambilan sampel menggunakan simple random sampling. Data dikumpulkan dengan menggunakan lembar observasi skala REEDA. Uji parametrik menggunakan uji paired t-test.

Rata-rata waktu penyembuhan ruptur perineum menggunakan perawatan air rebusan daun binahong adalah 6,33 hari sedangkan perawatan menggunakan air biasa adalah 8,27 hari. Hasil uji statistik didapatkan $\mathrm{p}$ value $=0,000$, artinya bahwa terdapat perbedaan efektivitas yang signifikan antara perawatan menggunakan air rebusan daun binahong dengan perawatan menggunakan air biasa terhadap waktu penyembuhan ruptur perineum pada ibu bersalin di Puskesmas Menes Kabupaten Pandeglang Provinsi Banten tahun 2019.

Perawatan ruptur perineum menggunakan air rebusan daun binahong lebih efektif dibandingkan dengan perawatan menggunakan air biasa.
\end{abstract}

Kata Kunci: Penyembuhan Ruptur Perineum, Air Rebusan Daun Binahong, Ibu Bersalin

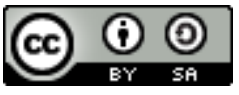

This is an open-acces article distributed under the terms of the Creative Commons Attribution-ShareAlike 4.0 International License.

\section{PENDAHULUAN}

Data World Health Organization (WHO) tahun 2016, melaporkan bahwa sebanyak 99\% AKI terjadi akibat masalah persalinan atau kelahiran dan sebanyak $81 \%$ AKI terjadi akibat komplikasi selama hamil dan bersalin, 25\% selama masa post partum. Faktor langsung penyebab tingginya AKI adalah perdarahan post partum (45\%), keracunan kehamilan (24\%), infeksi (11\%) dan partus lama atau macet (7\%). Komplikasi obstetrik umumnya terjadi pada waktu persalinan yang waktunya pendek yaitu sekitar 8 jam. Kasus laserasi atau ruptur perineum pada ibu bersalin tahun 2016 di seluruh dunia terjadi 2,7 juta orang. Angka ini diperkirakan mencapai 6,3 juta pada tahun 2050. Di Amerika 26 juta ibu bersalin yang 
mengalami laserasi perineum, $40 \%$ diantaranya mengalami laserasi perineum karena kelalaian bidannya dan ini akan membuat beban biaya kira-kira 10 juta dolar pertahun. Di Australia terdapat $20.000 \mathrm{ibu}$ bersalin yang mengalami laserasi perineum sedangkan di Asia laserasi perineum merupakan masalah yang cukup banyak dalam masyarakat, 50\% di dunia terjadi di Asia (WHO, 2016).

Angka Kematian Ibu (AKI) di Indonesia sebesar 228 per 100.000 kelahiran hidup. Kematian ibu secara langsung disebabkan oleh perdarahan post partum $(30,3 \%)$ dan hipertensi $(27,1 \%)$. Sedangkan kematian ibu secara tidak langsung disebabkan oleh penyakit yang sudah ada atau penyakit yang timbul sewaktu kehamilan yang berpengaruh terhadap kehamilan yaitu malaria $(13,4 \%)$ anemia $(11,9 \%)$, HIV/AIDS $(3,2 \%)$, dan penyakit kardiovaskular $(3,1 \%)$ (Kemenkes RI, 2017). Berdasarkan data Survey Demografi Kesehatan Indonesia (SDKI) menunjukkan bahwa di Indonesia laserasi atau ruptur perineum dialami oleh $75 \%$ ibu melahirkan pervaginam. Pervelensi ibu bersalin yang mengalami robekan perineum di Indonesia pada golongan umur 25-30 tahun yaitu 24\%, dan pada ibu umur 32-39 tahun sebesar 62\%. Pada pada tahun 2017 ditemukan bahwa dari total 1951 kelahiran spontan pervaginam, $57 \%$ ibu mendapat jahitan perineum, 28\% karena episiotomi dan 29\% karena robekan spontan (SDKI, 2018).

Angka Kematian Ibu di Provinsi Banten tahun 2017 sebesar 127 per 100.000 kelahiran hidup, sementara target nasional adalah 125 per 100.000 kelahiran hidup. Kematian ibu disebabkan oleh perdarahan post partum (37\%), eklampsia (21\%), infeksi jalan lahir (13\%) dan sebab lainnya (42\%) (Dinkes Provinsi Banten, 2018). Sedangkan AKI di Kabupaten Pandeglang pada tahun 2017 tercatat 14 orang $(0,09 \%)$ dari 14.689 ibu atau 95 per 100.000 kelahiran hidup (KH). Angka tersebut sudah sesuai dengan target SDGs yaitu 102/100.000 KH. AKI di Kabupaten Pandeglang disebabkan oleh perdarahan postpartum (34\%), infkesi jalan lahir (14\%), eklampsia (11\%) dan sebab lain (46\%) (Dinkes Kabupaten Pandeglang, 2018). Puskesmas Menes Kabupaten Pandeglang merupakan tempat pelayanan kesehatan masyarakat yang memberikan pelayan kesehatan salah satunya pelayanan ibu dan anak mulai dari ANC, Persalinan, Nifas, bayi, KB, Kespro KB, dll. Berdasarkan hasil presurvei awal di Puskesmas Menes didapatkan data jumlah ibu yang melahirkan pada bulan September tahun 2019 sebanyak 40 orang, dan mendapat perawatan nifas baik yang bersalin dengan luka jahitan maupun tidak dengan rata-rata perawatan 1 sampai 2 hari di Puskesmas Menes. Dari 40 ibu postpartum tersebut, yang mengalami ruptur sebanyak 30 orang, dengan rincian ruptur spontan sebanyak 20 orang dan yang dilakukan episiotomi 10 orang dan rata-rata perawatan luka hanya dengan menggunakan air biasa (Puskesmas Menes, 2019).

Salah satu perubahan yang terjadi pada ibu post partum yaitu adanya laserasi atau ruptur perineum. Laserasi Perineum adalah luka pada daerah muskular yang ditutupi kulit antar introitus vagina dan anus yang disebabkan oleh robekan karena persalinan (Reeder, 2014). Komplikasi yang terjadi dari laserasi perineum adalah penyembuhan luka yang terlambat bahkan terjadi infeksi. Dampak yang terjadi apabila penyembuhan luka terhambat seperti kesakitan dan rasa takut untuk bergerak, sehingga dapat menimbulkan banyak permasalahan diantaranya sub involusi uterus, pengeluaran lochea yang tidak lancar, dan perdarahan pasca partum yang merupakan penyebab pertama kematian ibu di Indonesia (Rahmawati, 2015).

Upaya untuk mencegah terjadinya infeksi laserasi perineum dapat diberikan dengan terapi farmakologis dan terapi nonfarmakologis. Terapi farmakologis adalah dengan pemberian obat antibiotik dan antiseptik (povidone iodine) untuk perawatan ruptur perineum akan tetapi obat dan bahan ini memiliki efek samping seperti alergi, menghambat pembuatan kolagen yang berfungsi untuk penyembuhan luka (Firdayanti, 2014). Sedangkan terapi nonfarmakologis yang dapat diberikan untuk mempercepat penyebuhan luka agar tidak terjadi infeksi adalah menggunakan daun binahong (Shabella, 2016). 
Berdasarkan hasil riset Widyastuti (2016) di Universitas Muhammadiyah Malang, membuktikan bahwa secara ilmiah manfaat binahong yaitu dapat mengobati luka. Berdasarkan hasil riset yang telah dilakukan diketahui bahwa daun binahong mengandung senyawa aktif flavonoid, alkaloid, terpenoid, dan saponin. Senyawa aktif flavonoid berperan langsung sebagai antibiotik dengan mengganggu fungsi dari mikroorganisme seperti bakteri dan virus. Aktivitas farmakologi dari flavonoid adalah sebagai antiinflamasi, analgesik, dan antioksidan. Nurul (2017) dalam penelitiannya juga menyebutkan bahwa sebagai obat luka, binahong mengandung beberapa kandungan kimia yaitu flvonoid, asam oleanolik, protein, saponin, dan asam askorbat. Kandungan asam askorbat pada tanaman ini penting untuk mengaktifkan enzim prolil hodroksilasi yang menunjang tahap hidroksilasi dalam pembentukan kolagen, sehingga dapat mempercepat proses penyembuhan luka (Susetya, 2016).

Penelitian yang dilakukan Wijayanti dan Rahayu (2016) tentang efektivitas air rebusan daun binahong terhadap penyembuhan ruptur perineum pada 22 responden didapatkan hasil 90,9\% penyembuhan ruptur perineum kategori baik. Hasil penelitian yang di lakukan oleh Milandiyah (2017) menyatakan bahwa ekstrak etanol daun binahong mampu menyambuhkan luka lebih baik dari pada povidoe iodine pada kulit kelinci. Penelitian tersebut juga didukung oleh Kaur (2016), menyatakan bahwa aplikasi pasta daun binahong secara topical menunjukkan hasil lebih baik dalam proses penyambuhan luka dibandingkan dengan $\mathrm{Na} \mathrm{Cl}$ $0,9 \%$ dan povidone iodine $5 \%$ pada kulit tikus, sehingga bisa digunakan sebagai alternatif pengobatan luka di rumah yang bersifat tradisional. Penelitian lain juga mendukung hal tersebut yaitu dilakukan oleh Oriza (2015), yang menyatakan bahwa ekstrak daun binahong dapat memperecepat penyembuhan luka sayat pada tikus putih dengan dosis efeltif yaitu konsentrasi $30 \%$, dibandingkan dengan povidone iodine. Penelitian lain dilakukan oleh Firzanah (2017), yang menyatakan bahwa ada pengaruh mengkonsumsi air rebusan daun binahong terhadap penyembuhan ruptur perineum pada ibu nifas.

Survei pendahuluan yang dilakukan oleh peneliti pada bulan Oktober tahun 2019 melalui wawancara kepada 5 ibu nifas di Puskesmas Menes Kabupaten Pandeglang, mereka mengatakan bahwa semua ibu nifas selama ini menggunakan air biasa untuk perawatan ruptur perineum dan tidak ada satu orang pun diantara mereka yang pernah menggunakan air rebusan daun binahong pasca melahirkan sebagai perawatan ruptur perineum.

Berdasarkan latar belakang yang telah diuraikan di atas, maka peneliti tertarik untuk melakukan penelitian tentang efektivitas air rebusan daun binahong terhadap penyembuhan ruptur perineum pada ibu bersalin di Puskesmas Menes Kabupaten Pandeglang Provinsi Banten tahun 2019.

\section{METODOLOGI PENELITIAN}

Penelitian ini menggunakan desain quasi experiment dengan rancangan two group with control post test design. Penelitian ini dibagi menjadi dua kelompok, yaitu kelompok kontrol dan kelompok intervensi. Kelompok kontrol akan diberikan perlakuan perawatan perineum menggunakan air biasa dan kelompok intervensi akan diberikan perlakuan perawatan perineum menggunakan air rebusan daun binahong.

Populasi dalam penelitian ini adalah ibu post partum spontan yang melakukan persalinan di Puskesmas Menes dengan jahitan perineum sebanyak 30 orang.

Sampel yang digunakan dalam penelitian ini adalah ibu post partum spontan dengan ruptur perineum sebanyak 30 responden, yang terbagi menjadi 2 kelompok. Kelompok intervensi sebanyak 15 orang, dan kelompok kontrol sebanyak 15 orang. Pengambilan sampel pada penelitian ini dilakukan dengan simple random sampling.

Penelitian ini dilaksanakan di Puskesmas Menes Kabupaten Pandeglang Provinsi Banten. Penelitian dimulai pada bulan Oktober tahun 2019 - Januari tahun 2020. 
Alat pengumpulan data dalam penelitian ini menggunakan lembar observasi skala REEDA untuk memeriksa dan mencatat proses penyembuhan ruptur perineum yang dimulai pada hari ke-2 sampai dengan hari ke-9 post partum.

\section{HASIL PENELITIAN}

\section{Uji Normalitas}

Tabel 4.1. Hasil Uji Normalitas Kolmogorov-Smirnov

\begin{tabular}{cccc}
\hline \multicolumn{2}{c}{ Data Air Rebusan Daun Binahong } & \multicolumn{2}{c}{ Data Air Biasa } \\
\hline \multirow{2}{*}{ Kolmogorov Smirnov $-Z$} & Sig. (2-tailed) & Kolmogorov Smirnov & Sig. (2-tailed) \\
\hline 1,116 & 0,166 & $-Z$ & 0,300 \\
\hline
\end{tabular}

Berdasarkan Tabel 4.1, hasil uji normalitas data air rebusan daun binahong diperoleh nilai Sig. 2-tailed sebesar $0,166 \geq 0,05$ dan data air biasa sebesar $0,300 \geq 0,05$. Artinya bahwa data observasi secara keseluruhan dikatakan berditribusi normal.

\section{Analisis Bivariat}

1. Rata-rata Waktu Penyembuhan Ruptur Perineum Pada Ibu Bersalin yang Diberi Perawatan Dengan Air Rebusan Daun Binahong dan Air Biasa

Tabel 4.2. Rata-Rata Waktu Penyembuhan Ruptur Perineum Pada Ibu Bersalin yang Diberi Perawatan Dengan Air Rebusan Daun Binahong dan Air Biasa di Puskesmas Menes Kabupaten Pandeglang

\begin{tabular}{ccccc}
\hline Penyembuhan Ruptur Perineum & Mean & SD & Min & Max \\
\hline Air Rebusan Daun Binahong & 6,33 & 0,724 & 5 hari & 7 hari \\
\hline Air Biasa & 8,27 & 0,704 & 7 hari & 9 hari \\
\hline
\end{tabular}

Berdasarkan tabel 4.2 diketahui bahwa rata-rata waktu penyembuhan ruptur perineum dengan menggunakan perawatan dengan air rebusan daun binahong adalah 6,33 hari dan standar deviasi 0,724 dengan waktu minimum adalah 5 hari dan maksimum 7 hari. Sedangkan ratarata waktu penyembuhan ruptur perineum dengan menggunakan perawatan dengan air biasa adalah 8,27 hari dan standar deviasi 0,704 dengan waktu minimum adalah 7 hari dan maksimum 9 hari.

2. Perbandingan Efektivitas Air Rebusan Daun Binahong dan Air Biasa Terhadap Penyembuhan Ruptur Perineum Pada Ibu Bersalin di Puskesmas Menes Kabupaten Pandeglang

Tabel 4.3. Perbandingan Efektivitas Air Rebusan Daun Binahong dan Air Biasa Terhadap Penyembuhan Ruptur Perineum Pada Ibu Bersalin di Puskesmas Menes Kabupaten Pandeglang

\begin{tabular}{cccccc}
\hline Penyembuhan Ruptur Perineum & n & Mean & SD & t-test & Sig. 2 (tailed) \\
\hline Air Rebusan Daun Binahong - Air Biasa & 30 & $-1,933$ & 0,704 & $-10,640$ & 0,000 \\
\hline
\end{tabular}

Berdasarkan hasil analisis bivariat pada Tabel 4.3 di atas, diketahui bahwa perbedaan rata-rata waktu penyembuhan ruptur perineum antara yang dirawat dengan menggunakan air rebusan daun binahong dan yang dirawat menggunakan air biasa adalah 1,933 hari dengan standar deviasi 0,704. Hasil uji statistik menggunakan uji paired t-test diperoleh nilai Sig. (2 tailed) sebesar 0,000. Dimana nilai signifikansi lebih kecil dari pada nilai $\alpha(0,000<0,05)$, yang berarti bahwa terdapat perbedaan waktu penyembuhan ruptur perineum menggunakan perawatan dengan air rebusan daun binahong dan perawatan dengan menggunakan air biasa. 


\section{PEMBAHASAN}

\section{Rata-Rata Waktu Penyembuhan Ruptur Perineum Pada Ibu Bersalin dengan Menggunakan Perawatan Air Rebusan Daun Binahong dan Air Biasa}

Hasil penelitian menunjukkan bahwa dari 15 responden yang dirawat menggunakan air rebusan daun binahong didapatkan rata-rata waktu penyembuhan ruptur perineum adalah 6,33 hari dan standar deviasi 0,724 dengan waktu minimum adalah 5 hari dan maksimum 7 hari. Sedangkan rata-rata waktu penyembuhan ruptur perineum dengan menggunakan perawatan dengan air biasa adalah 8,27 hari dan standar deviasi 0,704 dengan waktu minimum adalah 7 hari dan maksimum 9 hari.

Perawatan luka perineum sangat penting dilakukan untuk mempercepat proses penyembuhan. Tujuan perawatan perineum adalah mencegah terjadinya infeksi sehubungan dengan penyembuhan jaringan (Hamilton, 2014). Moorhouse et al. (2015) menambahkan bahwa tujuan perawatan perineum adalah mencegah terjadinya infeksi pada saluran reproduksi yang terjadi dalam 28 hari setelah kelahiran anak atau aborsi.

Tanaman binahong (Anredera cordifolia (Ten.) Steenis) adalah tanaman obat potensial yang dapat mengatasi berbagai jenis penyakit dan dapat menyembuhkan luka (Manoi, 2016). Rachmawati (2015) telah melakukan skrining fitokimia daun Binahong dengan melakukan maserasi terhadap serbuk kering daun dengan menggunakan pelarut n-heksana dan metanol didapatkan kandungan kimia berupa saponin triterpenoid, flavanoiod dan minyak atsiri. Selanjutnya hasil riset Widyastuti (2016) di Universitas Muhammadiyah Malang, membuktikan bahwa secara ilmiah manfaat binahong yaitu dapat mengobati luka. Berdasarkan hasil riset yang telah dilakukan diketahui bahwa daun binahong mengandung senyawa aktif flavonoid, alkaloid, terpenoid, dan saponin. Senyawa aktif flavonoid berperan langsung sebagai antibiotik dengan mengganggu fungsi dari mikroorganisme seperti bakteri dan virus. Aktivitas farmakologi dari flavonoid adalah sebagai antiinflamasi, analgesik, dan antioksidan.

Penelitian Paju et al. (2017) menyimpulkan bahwa binahong memiliki efektivitas penyembuh luka yang terinfeksi bakteri Staphylococcus aureus. Penelitian yang dilakukan Wijayanti dan Rahayu (2017) tentang efektivitas air rebusan daun binahong terhadap penyembuhan ruptur perineum didapatkan hasil 90,9\% penyembuhan ruptur perineum kategori baik. Hasil penelitian yang di lakukan oleh Milandiyah (2017) menyatakan bahwa ekstrak etanol daun binahong mampu menyambuhkan luka lebih baik dari pada povidoe iodine.

Hasil penelitian ini sejalan dengan penelitian Risneni dan Imrone (2018), yang menunjukkan bahwa 95\% ibu postpartum yang diberikan pengobatan dengan air biasa penyembuhan luka membuthkan waktu terpanjang selama lebih dari 8 hari dengan rata-rata waktu penyembuhan 7 hari, sedangkan 50\% responden yang diobati dengan air rebusan daun binahong rata-rata waktu penyembuhan luka membutuhkan waktu 5 hari. Hal ini didukung oleh penelitian Paunno (2019) di Puskesmas Letwaru Kabupaten Maluku Tengah, menunjukkan hasil bahwa $100 \%$ ibu nifas yang menggunakan air rebusan daun binahong untuk perawatan luka perineum spontan derajat 1 dan 2 , seluruhnya teridentifikasi mengalami penyembuhan yang cepat 5 hari, sedangkan yang menggunakan air biasa $20 \%$ ibu nifas teridenfifikasi mengalami percepatan penyembuhan luka 5 hari dan $80 \%$ ibu nifas mengalami penyembuhan luka perineum $>5$ hari.

Peneliti berasumsi bahwa upaya yang dapat dilakukan untuk mencegah terjadinya infeksi ruptur perineum dapat diberikan dengan terapi farmakologis dan terapi non farmakologis. Terapi farmakologis adalah dengan pemberian obat antibiotik (povidone iodine) untuk perawatan luka perineum akan tetapi obat dan bahan ini memiliki efek samping seperti alergi, menghambat pertumbuhan kolagen yang berfungsi untuk penyembuhan luka. Sedangkan terapi nonfarmakologi yang dapat di berikan untuk mempercepat penyembuhan 
luka perineum adalah menggunakan daun binahong. Terbukti bahwa kandungan fitokimia pada tanaman binahong efektif dapat menyembuhkan luka ruptur perineum dengan waktu yang cepat dibandingkan dengan perawatan menggunakan air biasa dan povidone iodine.

\section{Perbandingan Efektivitas Air Rebusan Daun Binahong dan Air Biasa Terhadap Penyembuhan Ruptur Perineum Pada Ibu Bersalin di Puskesmas Menes Kabupaten Pandeglang}

Hasil penelitian menunjukkan bahwa perbedaan rata-rata waktu penyembuhan ruptur perineum antara yang dirawat dengan menggunakan air rebusan daun binahong dan yang dirawat menggunakan air biasa adalah 1,933 hari dengan standar deviasi 0,704. Hasil uji statistik menggunakan uji paired t-test diperoleh nilai Sig. (2 tailed) sebesar 0,000. Dimana nilai signifikansi lebih kecil dari pada nilai $\alpha(0,000<0,05)$, yang berarti bahwa terdapat perbedaan efektivitas yang signifikan antara penyembuhan ruptur perineum dengan menggunakan perawatan air rebusan daun binahong dan perawatan dengan menggunakan air biasa, dimana kedua perawatan tersebut sama-sama efektif dalam penyembuhan ruptur perineum, namun perawatan dengan menggunakan air rebusan daun binahong lebih efektif dibandingkan dengan perawatan menggunakan air biasa.

Sebagai obat luka binahong mengandung beberapa kandungan fitokimia yaitu flavonoid, asam oleanolik, protein, saponin, dan asam askorbat. Kandungan asam askrobat pada tanaman ini penting untuk mengaktifkan enzim prolil hodroksilasi yang menunjang tahap hidroksilasi dalam pembentukan kolagen, sehingga dapat mempercepat proses penyembuhan luka (Susetya , 2016). Polifenol dan saponin berfungsi sebagai anti bakteri (Wardani, 2015). Pemberian daun binahong pada luka membantu penyembuhan luka dengan pembentukan jaringan granulasi yang lebih banyak dan reepitalisasi terjadi lebih cepat dibandingkan dengan luka yang tidak diberi daun binahong (Ariani, 2016).

Hasil penelitian ini sejalan dengan penelitian yang dilakukan oleh Gurwinder (2018) yang menunjukkan hasil bahwa terdapat perbedaan sangat signifikan antara perbandingan daun binahong dan air biasa pada hari ke-12, dengan $\mathrm{p}=0,001(\mathrm{p}<0,05)$. Dalam penelitiannya dijelaskan bahwa aplikasi pasta daun Binahong menunjukkan hasil yang lebih baik dalam proses penyembuhan luka. Hal ini didukung oleh penelitian Zulmi (2019) yang menunjukkan hasil bahwa pada kelompok intervensi menunjukkan 52,71\% disembuhkan setelah mendapatkan perawatan untuk luka perineum menggunakan rebusan daun binahong yang duduk dan direndam. Di sisi lain, pada kelompok kontrol, hanya menggunakan air bersih menunjukkan $27,90 \%$ pulih. Hasil Uji Wilcoxon didapat nilai ( $p<0,05)$. Berdasarkan hasil ini ada efek rebusan daun binahong yang duduk dan direndam pada penyembuhan luka perineum untuk ibu nifas.

Peneliti berasumsi bahwa ibu post partum yang melakukan perawatan ruptur perineum menggunakan air rebusan daun binahong sebagian besar mengalami proses penyembuhan luka perineum yang lebih cepat dibandingkan dengan menggunakan air biasa. Hal ini karena tanaman binahong mengandung antiseptik yang mampu membunuh kuman dan dapat meningkatkan daya tahan terhadap infeksi serta mempercepat penyembuhan luka. Selain dari manfaat kandungan fitokimia tanaman binahong, penyembuhan luka perineum cepat juga dapat dipengaruhi oleh faktor usia dan nutrisi responden, nutrisi yang mengandung protein akan meningkatkan daya imunitas tubuh, akan tetapi kondisi kesehatan ibu baik secara fisik maupun mental dapat menyebabkan lamanya penyembuhan.

\section{KESIMPULAN}

1. Rerata waktu penyembuhan ruptur perineum dengan perawatan menggunakan air rebusan daun binahong adalah 6,33 hari dengan standar deviasi 0,724 dimana waktu minimum penyembuhan adalah 5 hari dan maksimum 7 hari. 
2. Rerata waktu penyembuhan ruptur perineum dengan perawatan menggunakan air biasa 8,27 hari dengan standar deviasi 0,704 dimana waktu minimum penyembuhan adalah 7 hari dan maksimum 9 hari.

3. Perbedaan rata-rata waktu penyembuhan ruptur perineum antara yang dirawat dengan menggunakan air rebusan daun binahong dan yang dirawat menggunakan air biasa adalah 1,933 hari dengan standar deviasi 0,704.

4. Terdapat perbedaan efektivitas yang signifikan antara perawatan ruptur perineum dengan perawatan menggunakan air rebusan daun binahong dan perawatan dengan menggunakan air biasa terhadap waktu penyembuhan ruptur perineum pada ibu bersalin di Puskesmas Menes Kabupaten Pandeglang Provinsi Banten tahun 2019.

\section{DAFTAR PUSTAKA}

Dewanty, N., 2014, Efektifitas Air Rebusan Simplisia Daun Binahong (Anredera Cordifolia (Tenore) Steen) Untuk Penyembuhan Luka Perineum Pada Ibu Nifas di Klinik Murniati Kecamatan Kota Kisaran Barat, Jurnal Ilmiah Kefarmasian UAD, Vol. 4 (3), No. 2, 25 26.

Dinkes Kabupaten Pandeglang, 2018, Profil Kesehatan Provinsi Banten Tahun 2018, Serang, Banten.

Dinkes Provinsi Banten, 2018, Profil Kesehatan Kabupaten Pandeglang Tahun 2018, Serang, Banten.

Firdayanti, N., 2014, Asuhan Kebidanan Pada Masa Nifas, Salemba Medika, Jakarta.

Firzanah, H., 2017, Pengaruh Air Rebusan Daun Binahong Terhadap Penyembuhan Luka Perineum di BPS Ny. Dian Susiloririni, A.Md Keb. Nggronggot Nganjuk, Jurnal Kebidanan Univ. Mayjen Sungkono Mojokerto, Vol. 2 (4), No. 3, 34-41.

Kaur, U.R., 2016, Pengaruh Salep Eklstrak Daun Binahong (Anredera Cordifolia (Ten.) Steenis) Fraksi Etanol Terhadap Kesembuhan Luka Iris Secara Fisik Pada Kulit Tikus Putih (Rattus Norvegicus), Jurnal Ilmiah Kefarmasian UAD, Vol. 6 (2), No. 7, 56-59.

Kemenkes R.I., 2018, Infodatin, Pusat Data dan Informasi, Kementerian Kesehatan Republik Indonesia, Jakarta.

Manoi, F., 2016, Binahong (Anredera cordifolia (Ten) Steenis) Sebagai Obat, Jurnal Warta Penelitian dan Pengembangan Tanaman Industri, Jurnal Artikel Penelitian, (Online), Volume 15 Nomor 1:3, Diakses tanggal 30 Oktober 2019.

Milandiyah, I., 2017, Khasiat Daun Binahong (Anredera Cordifolia (Ten.) Steenis) Terhadap Pembentukan Jaringan Granulasi dan Reepitelisasi Penyembuhan Luka Terbuka Kulit Kelinci, Jurnal (e-journal) Ilmiah UNSRAT, Vol. 6 (5), No.7, 67-72.

Nurul, P., 2017, Khasiat Daun Binahong (Anredera Cordifolia (Ten.) Steenis) Terhadap Pembentukan Jaringan Granulasi dan Reepitelisasi Penyembuhan Luka, Jurnal Ilmiah Farmasi UNSRAT, Vol. 4 (3), No. 4, 46-53.

Paju, L., Steen, M dan Cooper, K.A, 2017, Effectiveness Of Binahong Decoction Water (Anredera Cordifolia (Ten) Steenis) For Perineal Wound Healing, International Journal of Research in Medical Sciences, 2017; Vol. 6: 432-436. 
Parwata, Y., Subagio, R., dan Junedy, S., 2014, Tanaman Terpilih untuk Pengobatan Berbagai Jenis Kanker, Seri Agrisehat, Tumbuhan Obat dan Khasiatnya, Seri 1, 2, dan 3, Penebar Swadaya, Jakarta.

Paunno, L., 2019, Pengaruh Air Rebusan Daun Binahong Terhadap Penyembuhan Luka Perineum Pada Ibu Nifas di Puskesmas Letwaru Kecamatan Kota Masohi Kabupaten Maluku Tengah, Jurnal Penelitian Kesehatan Suara Forikes, Vol. 9, No. 3, ISSN 20863098 .

Puskesmas Menes, 2019, Data Rekam Medis Puskesmas Menes Tahun 2017-2019, Menes, Pandeglang.

Risneni, T., dan Imron, R., 2018, Differences of Effectiveness of Povidone-Iodine and Binahong Leaf Stew Water on the Healing of Perineal Laceration in Postpartum Mothers, International Journal of Medical Science And Clinical Research, Vol.2 (3), No. 2.

Shabella, D., 2016, Terapi Daun Binahong; Dahstnya Khasiat Daun Binahong Untuk Menumpas Penyakit, Cable Book, Klaten.

Susetya, D., 2016, Khasiat dan Manfaat Daun Ajaib Binahong Cetakan I, Pustaka Baru Press, Yogyakarta.

Wardhani, K., dan Nanik, S., 2016, Uji Aktifitas Antibakteri Ekstrak Etil Asetat Daun Binahong (Anredera Scandens (L) Moq.), Jurnal Ilmiah Kefarmasian UAD, Vol. 2 No. 1, ISSN 2111- 2206.

White, Y.E., 2015, Maternal and Neonatal Nursing: Family Centered Care, Third Edition, Lippincot Company, Philadelphia.

WHO, 2016, The Global Prevalance Of Anemia In 2016, Available from web. http://apps.who.int/iris/bitstream/10665, diakses pada 29 Oktober 2019.

Widyastuti, T., 2016, Kandungan Flavonoid dan Kapasitas Antioksidan Total Ekstrak Etanol Daun Binahong, Jurnal Ilmiah Farmasi UMM Vol. 2 No. 1 (2) 2013, ISSN 2302- 2493.

Wijayanti, K., dan Rahayu, H.S.E., 2017, Effectiveness Of Binahong Decoction Water (Anredera Cordifolia (Ten) Steenis) For Perineal Wound Healing, International Journal of Research in Medical Sciences, Vol. 2 (4), No. 3, 34-41.

Yellia, M., 2016., Khasiat Daun Binahong (Anredera Cordifolia (Ten) Terhadap Pembentukan Jaringan Granulasi dan Reepitalisasi Penyembuhan Luka, Jurnal Kesehatan UNSRAT, Vol. 4 (2), No. 2.

Zulmi, D., 2019, The Effect Of Sitting And Soaking Therapy With Binahong Leaf (Anredera Cordifolia) Decoction On Perineal Wound Healing, International Journal Midwife, Vol. 8, No. 3, ISSN 1124-2129. 